\title{
BMJ Global Health Impact of United States political sanctions on international collaborations and research in Iran
}

\author{
Fatemeh Kokabisaghi, ${ }^{1}$ Andrew C Miller, ${ }^{\circ}$ Farshid R Bashar, ${ }^{3}$ Mahmood Salesi, ${ }^{4}$ \\ Ali A K Zarchi, ${ }^{5}$ Abdalsamad Keramatfar, ${ }^{6}$ Mohammad A Pourhoseingholi, ${ }^{7}$ \\ Hosein Amini, ${ }^{8}$ Amir Vahedian-Azimi ${ }^{9}$
}

To cite: Kokabisaghi F, Miller AC, Bashar FR, et al. Impact of United States political sanctions on international collaborations and research in Iran. BMJ Global Health 2019;4:e001692. doi:10.1136/ bmjgh-2019-001692

Handling editor Seye Abimbola

- Additional material is published online only. To view please visit the journal online (http://dx.doi.org/10.1136/ bmjgh-2019-001692).

Received 3 May 2019 Revised 17 June 2019 Accepted 17 June 2019
Check for updates

(c) Author(s) (or their employer(s)) 2019. Re-use permitted under CC BY-NC. No commercial re-use. See rights and permissions. Published by BMJ.

For numbered affiliations see end of article.

Correspondence to Dr Amir Vahedian-Azimi; Amirvahedian63@gmail.com

\section{ABSTRACT}

International research collaborations improve individual, institutional and governmental capacities to respond to health crises and inequalities but may be greatly affected by political environments. Iran ranks highly in tertiary education, productivity growth, knowledge impact and successful patent applications. In many countries, economic hardship has correlated with increased international research collaborations. Some have hypothesised that financial constraint drives scholars to seek outside collaborations for cost and risk sharing, and to access funding, materials and patient populations otherwise unavailable. This paper explores the history and importance of US political sanctions on the health of Iran's academic sector. Although Iran's international research collaborations increased during periods of increased sanctions, the Pearson correlation coefficient between gross domestic product and international research collaborations was not significant $(r=0.183$, $p=0.417$ ). This indicates that other factors are at least in part responsible. Additionally, we found Iran's quantitative (eg, publication number) and qualitative (eg, visibility indices) publishing metrics to be discordant (two-tailed Mann-Kendall trend; $p<0.0002$ for both). Reasons for this are multifactorial, including increased indexing of Iranian journals, willingness of lower visibility journals to handle manuscripts with Iranian authors, widespread linkage of career advancement to science visibility indices, and others. During periods of increased sanctions, Iranian scholars were increasingly denied opportunities to publish scientific findings, attend scientific meetings, access to essential medical and laboratory supplies and information resources. We conclude that academic boycotts violate researchers' freedom and curtail progress. Free exchange of ideas irrespective of creed is needed to optimize global scientific progress.

\section{INTRODUCTION}

Globalisation is enhanced by international scientific and research collaboration. ${ }^{12}$ Rates of international research collaboration have increased sharply in recent decades, with internationally co-authored papers rising from $13.2 \%(2000)$ to $19.2 \%(2013) .^{3}{ }^{4}$
Summary box

- Global rates of international research collaboration have increased sharply in recent decades

- Iran's international research collaboration rate rose over recent periods of increased sanctions; however, evidence suggests that factors other than economic restrictions may be influencing this.

- Iran's publication rates have risen during recent periods of increased sanctions; however, its quantitative and qualitative metrics are discordant.

- Reasons for Iran's publication discordance may include increased indexing of Iranian journals in scholarly databases, willingness of lower visibility journals to handle manuscripts with Iranian authors, widespread linkage of career advancement to science visibility indices, and others.

- The World Medical Association rejects academic sanctions or boycotts and calls on all national medical associations to resist the imposition of such restrictions by every means at their disposal.

International research collaborations benefit society, enrich scientific lives and facilitate networking. ${ }^{5}$ Moreover, manuscripts, journal strength and citation numbers increase. ${ }^{6}$ Reasons for the rapid expansion of international research collaborations include: (1) improved research capacity (individual and institutional); (2) resource sharing ${ }^{1}$; (3) access to specialists (or patient population) not proximately available; (4) helping the scientific community stay up-to-date on cutting-edge advancements ${ }^{7}$; and (5) mitigating health inequities. ${ }^{8}{ }^{9}$ As such, international research collaborations are less a research quality indicator than a means to reach it. ${ }^{9}$

Information technology and communication systems improvements (particularly the internet) have facilitated rapid and extensive exchange of information, expertise and ideas across political, linguistic and cultural 
barriers. ${ }^{38}$ In particular, inexpensive and readily available modalities such as ResearchGate (ResearchGate Gmbh, Berlin, Germany), Mendeley (Mendeley Ltd, London, UK), LinkedIn (Microsoft Corp, Sunnyvale, California, USA), Facebook (Facebook Inc, Menlo Park, California, USA) and Twitter (Twitter Inc, San Francisco, California, USA) have facilitated an explosion in international research collaborations and data sharing. ${ }^{3}$ Moreover, video call and teleconference technologies defray travel and meeting costs. Academics, practitioners and policymakers alike have access to networks to coordinate and facilitate projects and foster dialogue, engagement and collective action. ${ }^{2} 1011$

Despite its merits, international research collaboration can be greatly affected by political environments including political sanctions and academic boycotts. This is currently the case in Iran. We endeavoured to examine the impact of US-imposed political and economic sanctions on international research collaborations among Iranian entities.

\section{SANCTIONS AND IRAN History}

At the international level, sanctions are state-supported measures aimed to coerce another to conform to an international agreement or conduct norms, typically by restrictions in trade or official sporting participation. Over recent decades they have increasingly been used as an alternative to armed conflict. In 2010, Iran faced sanctions from the United Nations (UN) Security Council (Resolution No 1929) over issues regarding its nuclear programme. ${ }^{12}$ In 2015, Iran and a group of world powers including the USA, UK, France, Russia, Germany and China (so called P5 +1 ) agreed on a nuclear deal framework in the Joint Comprehensive Plan of Action. ${ }^{13}$ According to this agreement, Iran was required to reduce its nuclear activities and facilities significantly for economic sanctions to be lifted. Despite early success, the US government later announced (May 2018) its intent to withdraw from this agreement and reinstate sanctions aimed to undermine Iran's nuclear and military industries. $^{12} 14$

\section{General economic impact}

Iran is the third most populous Eastern Mediterranean country. ${ }^{15}$ The economic sanctions limiting foreign trade cooperation with Iran (and entities doing business with Iran) have extended far beyond the initial intended purpose. ${ }^{16}$ The ban on aircraft parts endangered lives. ${ }^{17}$ The fuel trade ban resulted in forced substitution of imported fuel with poorly refined domestic fuel, causing adverse health effects from increased air and environmental pollution. ${ }^{18}$ As crude oil exports and associated revenues decreased, the foreign holdings of financial institutions were frozen, banks were isolated from the global financial system and imports were restricted. Access to the dollar and euro (needed to import a range of goods) decreased, and as the currency was devalued, inflation, unemployment and poverty rose. Moreover, as Iran's economic health declined, inflation has fluctuated widely, household incomes have fallen and the health and welfare of its people (and neighbours) has been jeopardised in ways previously demonstrated in Burundi, Cuba, Haiti, Iraq, Nicaragua and the former Yugoslavia. ${ }^{17} 2021$

\section{Scientific and health impact}

The economic sanctions imposed on Iran undermined the transfer of scientific knowledge, technology, medication and impeded research collaboration. Iranian healthcare needs are mainly provided by the government. As a significant portion of governmental income is derived from oil exports, economic sanctions targeting oil exports directly impaired health services. The health services decline has limited critical medication access. ${ }^{22} 23$ Hinderances of quality control technologies and pharmaceutical production have disrupted medication production and distribution. ${ }^{24} 25$

The health effects of sanctions may be due in part to deterioration of social determinants of health including: income, social status, employment, social environments and personal coping skills. ${ }^{26}$ Moreover, the most vulnerable are the most affected. ${ }^{27} 28$ According to the WHO, death rates due to self-harm rose from 5.9 to 6.1 per 100000 persons during the 2011-2014 period, returning to 5.91 year after the sanctions were lifted. Moreover, deaths due to interpersonal violence rose from an average of 2.0 to 2.7 per 100000 persons during the period of the sanctions. ${ }^{29}$ These trends, along with a corresponding increase in substance abuse, ${ }^{30} 31$ likely reflect a deterioration in healthcare during the period of intense economic sanctions. ${ }^{26}$

Unfortunately, the reach of the effects has extended beyond Iran to the greater Middle East region. Iran ranks third globally for hosted refugees, and incurs great cost to provide them with medical care. ${ }^{32}$ Additionally, Iran treats $>300000$ medical tourists (2013) annually from neighbouring countries including Afghanistan, Azerbaijan, Bahrain, Iraq, Kuwait, Lebanon, Pakistan, Saudi Arabia, Syria, Turkey and Turkmenistan. ${ }^{33}$ Furthermore, Iran supports medical care, health research and medical education growth in Afghanistan, Iraq and other neighbouring countries. In Afghanistan, Iran provides free polio vaccines, has worked to improve the quality of blood transfusion methods and product, and even established the first organ transplantation centre.

\section{IMPACT OF SANCTIONS ON IRAN'S RESEARCH AND PUBLISHING}

Iran has a young population, with $40 \%$ of the population aged $\leq 25$ years (figure 1 ). ${ }^{34} 35$ In recent years, enrollment in tertiary educational institutions has risen from 154000 (1975) to 4083000 (2017), ${ }^{36}$ with education expenditures exceeding the global average. ${ }^{37}$ Iran ranks high globally in science and engineering graduates (3rd), 


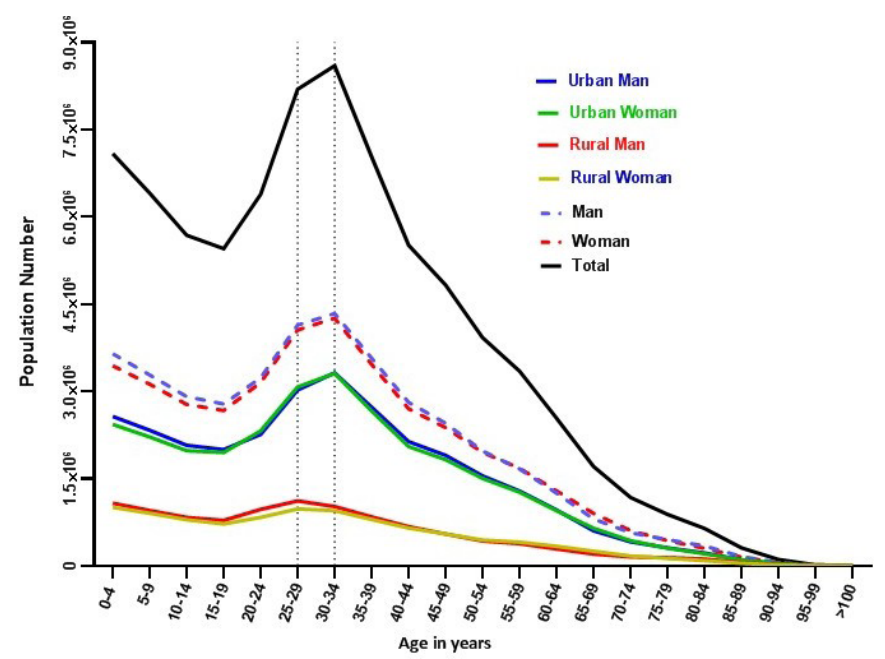

Figure 1 Iranian urban and non-urban population.

tertiary education (3rd), knowledge impact (12th) and science and technical publications (32nd). ${ }^{3839}$ As recently as 1996, Iran ranked first globally for manuscripts with international collaboration (figure $2 \mathrm{C}$ ). ${ }^{40}$

\section{International research collaboration}

Despite economic restrictions, Iran's international research collaboration rate rose from 2010 to 2015; however, numbers lagged behind those of many western (Canada, Germany, USA, UK), Middle Eastern (KSA, Iraq, Qatar, Egypt) and Asian countries (China, Japan, Malaysia) (figure 2). ${ }^{40}$ The reason for this rise is multifactorial. First, Iranian entities may have needed to engage in external collaboration to continue academic pursuits given a scarcity of resources, funding and applied external blockades. The drop in Iran's international research collaborations when sanctions were lessened from 1996 to 2004 lends credence to this hypothesis. Similar rises in international research collaborations were observed during periods of sanctions and financial constraint in Iraq following the second Iraq war (figure 2A). ${ }^{40}$ Additionally, similar trends were observed in many western countries (Australia, Canada, UK, USA) following the financial crisis of 2007-2008 (figure 2B). ${ }^{40}$ To assess this we calculated the Pearson correlation coefficient between gross domestic product (GDP) and international research collaborations (see online Supplemental appendix 1 for methods). Although suggestive, the relationship between Iran's GDP and international research collaborations was not significant $(r=0.183, p=0.417)$, suggesting other non-economic factors are also influencing this observation. ${ }^{41}$

A second factor contributing to the increase in Iran's international research collaborations is communication technologies. Data sharing and social networking websites have enabled researchers to collaborate in ways not previously possible. Data are currently lacking to further assess this relationship.

Lastly, the greater meaning implied by an increase in international research collaborations is not clear. A high level of international research collaboration could indicate either dependence or expertise. It is unclear which (if either) applies to Iran.

\section{Publishing}

Publication metrics may be viewed quantitatively (eg, publication number) or qualitatively (eg, visibility indices). Qualitative metrics are important as article numbers only describe the basis of visibility, not the perception.
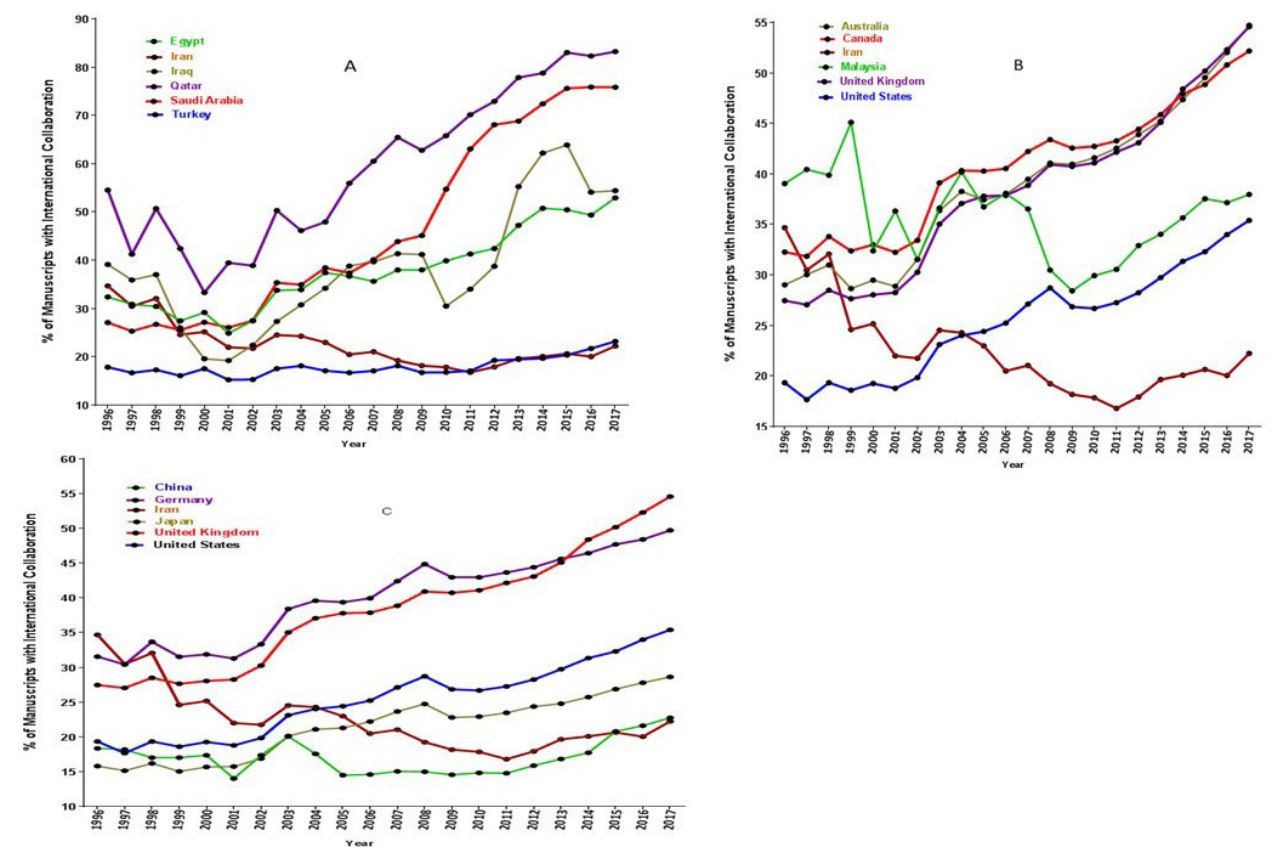

Figure 2 Rates of international research collaboration: (A) Comparison of Iran with the five Middle East countries that collaborate the most with them. (B) Comparison of Iran with the five countries (any region) that collaborate the most with them. (C) Comparison of Iran with the five countries that engage in the most international collaboration. 
As recently as 1996, Iran led other leading countries (China, Germany, Japan, UK, USA) in terms of manuscripts with international research collaborations (figure 2).$^{40}$ However, as of 2017 they ranked last among the same cohort. Even so, Iran's publication totals have followed global trends by rising steadily since 2011 (table 1). Despite trailing western nations, Iran and Turkey account for nearly half of all Organisation of Islamic Cooperation (OIC) member country scientific manuscripts. ${ }^{42}$ To investigate whether the rise in Iran's publications during recent periods of increased US sanctions is linked to Iran's economic stress, a two-tailed Mann-Kendall trend was performed for both quantitative and qualitative metrics (see online Supplemental appendix for methods). Discordance was observed between Iran's quantitative and qualitative global and Middle East rankings (figure 3; $\mathrm{p}<0.0002$ for both). ${ }^{43} 44$

The reasons for these findings are multifactorial, including increased indexing of Iranian journals, willingness of lower visibility journals to handle manuscripts with Iranian authors, widespread linkage of career advancement to science visibility indices, and others. In the two decades following Iran's revolution, almost no articles published in Iranian journals were cited or indexed in databases such as PubMed. ${ }^{45}$ In the past 15 years, however, the number of Iranian journals (and requisite citations) cited in PubMed has rapidly increased, ${ }^{45}$ resulting in improved article identification.

Additionally, widespread linkage of career advancement to science visibility indices may be contributing as well. Iranian policy makers adopted an approach whereby scientists were assessed based on science visibility indexes, including the number of publications in indexed journals. ${ }^{45}$ In the past two decades Iran began to support the development of internationally recognised journals and has used publications as a main indicator of performance. ${ }^{45}$ This has contributed to the increased publication numbers in indexed journals by Iranian entities.

As pertains to the discordance between Iran's quantitative and qualitative metrics, publishing embargoes likely play a role. Owing to fear of unwittingly violating the terms of the sanctions, many journal and publishers displayed an unwillingness to handle manuscripts with Iranian authors (or entities). As such, many Iranian authors were forced to publish findings in fledgling (newly indexed) journals, thereby decreasing their overall visibility.

\section{Scientific innovation}

Lastly, despite sanctions, Iran has demonstrated steady growth in scientific innovation. Iran rose 10 positions to 65 th globally (16th of 34 middle-income countries) in the 2018 Global Innovation Index, a measure based on 80 innovation performance indicators. ${ }^{39}$ Their major strength is the Innovation Efficiency Ratio (ranked 11th globally), a measure of how much innovation output a given country is getting for its inputs. ${ }^{39}$ Iran ranks high globally in productivity growth $(1 \mathrm{st}),{ }^{42}$ knowledge impact

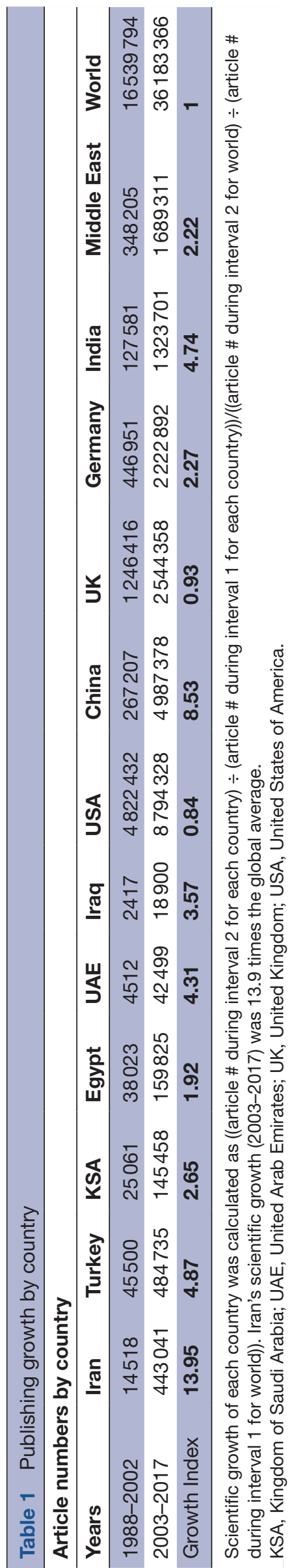



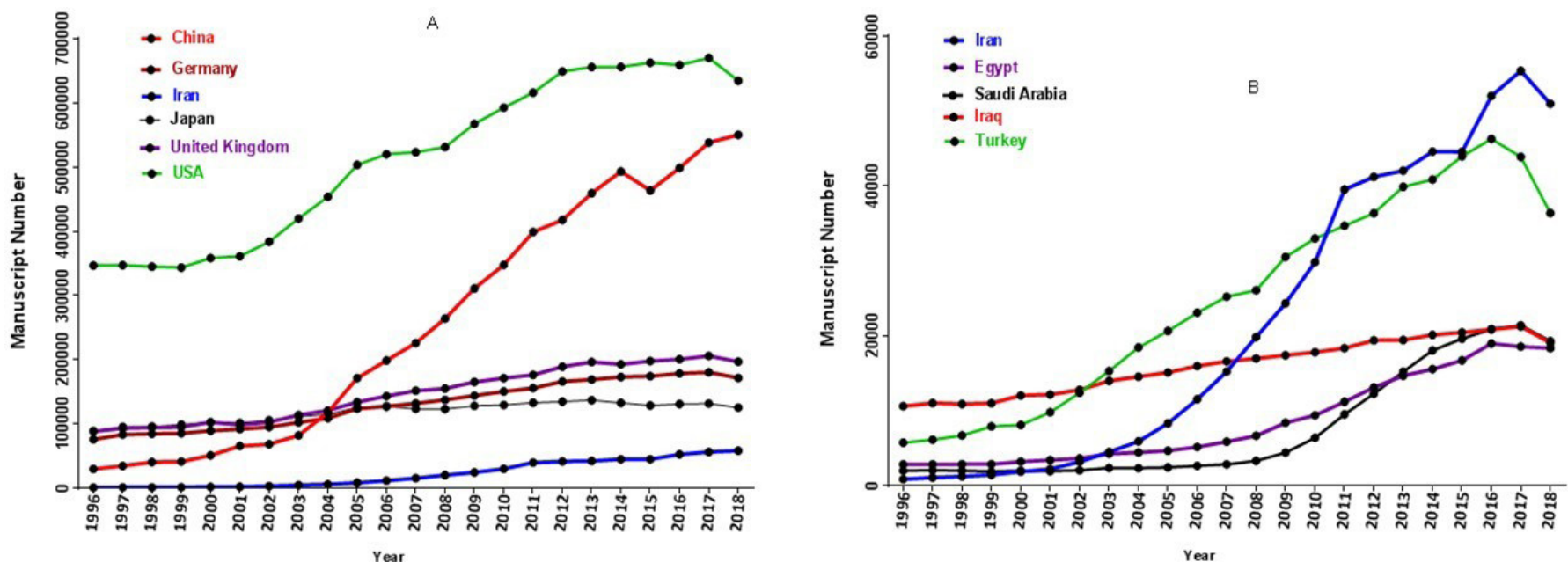

Figure 3 (A) Number of available papers of the top five countries in the world along with Iran. (B) Number of available papers of the top five countries in the Middle East.

(12th) and patents by origin (14th; 1st among OIC members). ${ }^{38} 39$ However, it performs weakly in the areas of investment and knowledge absorption. ${ }^{19}$

\section{SANCTION EFFICACY AND ACADEMIA'S RESPONSE}

Modern science is vulnerable to political sanctions. The World Medical Association (WMA) describes academic sanctions or boycotts as 'discriminatory restrictions on academic, professional and scientific freedoms that deny or exclude physicians and others from educational, cultural and scientific meetings and other opportunities for the exchange of information and knowledge, the purpose of such restrictions being to protest the social and political policies of governments'. ${ }^{18}$ By discriminating against physicians and patients on grounds of political persuasion (or decisions of their governments), academic boycotts particularly affect the healthcare of the vulnerable and disadvantaged; often sparing the very populations that prompted the sanctions. ${ }^{24}$ The WMA rejects such restrictions and calls on all national medical associations 'to resist the imposition of such restrictions by every means at their disposal'. ${ }^{4}$

Available evidence suggests that academic boycotts are not successful tools to achieve political ends. For example, South Africa experienced an academic boycott over apartheid policies. One study found that $57.3 \%$ of South African academics reported directly experiencing the effects of boycott tactics including manuscript rejection, denied opportunities to participate in scientific meetings, denied international research collaboration opportunities or impaired information resource access. ${ }^{46}$ Similarly, Iraq sanctions resulted in impaired access to medical literature, inability to publish in western journals, denied opportunities to participate in scientific meetings, scarce medical supplies and an overall deterioration of the health system. ${ }^{47}$ A similar fate has now befallen Iranian scientists. The blockade of currency exchange prevents paying fees (publication, registration, membership), ${ }^{25}$ impeding international research collaborations ${ }^{44}$ and causing many journals (and publishing companies) to refuse to handle papers submitted by Iranian entities. ${ }^{48}$ Furthermore, IP address blocking can further limit access to software and online resources. The impact of this cannot be overstated. Beyond impeding productivity and progress, sanctions directly impede the promotion and tenure process of Iran's academics, thereby limiting income and their ability to care for their families. Metrics such as the Impact Factor have become an integral part of the promotion and tenure process in Iranian universities. Being blocked from publishing, forced to publish in lower impact journals and obstructed from presenting at international meetings prevents or delays academics from reaching institutional benchmarks for career advancement.

Publishing embargoes were criticised by the Committee on Publication Ethics (COPE), which indicated that 'editorial decisions should not be affected by the origins of the manuscript, including the nationality, ethnicity, political beliefs, race, or religion of the authors. ${ }^{50}$ Furthermore, decisions to edit and publish should not be determined by the policies of governments or other agencies outside of the journal itself'. ${ }^{51}$ Subsequently, Elsevier changed its policy stating that manuscripts submitted by authors from sanctioned countries may be handled if they have one of the following criteria: (1) the author is not acting as an official representative of a sanctioned government; (2) (s) he acts on behalf of his government's education or research institution; or (3) he/she is publishing on behalf of his government institution which is not primarily an educational or research institution and the journal does not suggest substantive editing. ${ }^{50} 52$ Despite this, many editors remain conservative due to the fear of penalty or liability since instructions for manuscript handling and the definition of government employee remain unclear. ${ }^{53}$

Some publishers have sought to level the playing field by lowering barriers and defending the journal's right to publish for merit rather than political will. ${ }^{5455}$ The BMJ Publishing Group has waived publication fees for open 
access publications heralding from Iran to bypass bank transaction barriers. The Lancet declared that it welcomes research from scholars of all countries, including Iran. ${ }^{48}$ They added that:

'We are disappointed that some publishers have created the impression that work from Iran should be discriminated against. This attitude is contrary to the spirit and values of global science. We are currently working to deepen our relationship with Iranian medical and public health scientists, and we look forward to publishing the results of that collaboration, which, we hope, will include Iran's Ministry of Health'. ${ }^{56}$

Beyond publishing woes, foreign-sponsored clinical trials in Iran have been terminated or suspended. For example, a Wellcome Trust initiative to reduce urban health inequalities in six pilot cities (including Tehran) was prevented by obstructing research funds transfer from the UK to Iran ${ }^{57}$ Similarly, researchers at the Tehran University of Medical Sciences who teamed up with investigators at the Icahn School of Medicine at Mount Sinai in New York City for a US National Institutes of Healthfunded study on cardiovascular disease patterns in Iran's Golestan province received similar bad news when Mount Sinai was unable to transfer the Iranian share of the grant to Tehran. ${ }^{58}$

After the $\mathrm{P} 5+1$ agreement on lifting sanctions according to the Joint Comprehensive Plan of Action, advancements in Iranian higher education, research and relief of publishing restrictions were expected. ${ }^{42}$ However, the US withdrawal from the agreement, and subsequent new sanctions, has again derailed scientific progress. What is different this time is that the US government has threatened criminal prosecution of US citizens, residents and scientists who collaborate with Iranian entities. ${ }^{59}$

\section{CONCLUSION}

Globalisation is enhanced by international research collaborations. Information sharing and international collaboration is key to mastering the challenges the modern world faces. Although we found an increase in Iran's international research collaborations and publications during periods of increased sanctions, data suggest that other non-economic factors are at least in part responsible. During periods of increased sanctions, Iranian scholars were increasingly denied opportunities to publish scientific findings, attend scientific meetings, access to essential medical and laboratory supplies, and information resources. We conclude that academic boycotts violate researchers' freedom and curtail progress. Free exchange of ideas irrespective of creed is needed to optimise global scientific progress.

${ }^{1}$ Healthcare and Law Department, School of Health Policy and Management, Erasmus Universiteit Rotterdam, Rotterdam, The Netherlands

${ }^{2}$ Department of Emergency Medicine, East Carolina University Brody School of Medicine, Greenville, North Carolina, USA
}

${ }^{3}$ Department of Anesthesiology and Critical Care, School of Medicine, Hamadan University of Medical Sciences, Hamadan, Iran

${ }^{4}$ Chemical Injuries Research Center, Systems Biology and Poisonings Institute,

Baqiyatallah University of Medical Sciences, Tehran, Iran

${ }^{5}$ Department of Epidemiology and Biostatistics, Baqiyatallah University of Medical Sciences, Tehran, Iran

${ }^{6}$ Scientific Information Database, Tehran, Iran

${ }^{7}$ Gastroenterology and Liver Diseases Research Center, Shaheed Beheshti

University of Medical Sciences, Tehran, Iran

${ }^{8}$ Department of Epidemiology, Iran University of Medical Sciences, Tehran, Iran

${ }^{9}$ Trauma Research Center, Nursing Faculty, Baqiyatallah University of Medical Sciences, Tehran, Iran

Contributors All authors have contributed to each stage of manuscript design and preparation.

Funding The authors have not declared a specific grant for this research from any funding agency in the public, commercial or not-for-profit sectors.

Competing interests None declared.

Patient consent for publication Not required.

Provenance and peer review Not commissioned; externally peer reviewed.

Data availability statement All discussed data is publically available. No additional data is available.

Open access This is an open access article distributed in accordance with the Creative Commons Attribution Non Commercial (CC BY-NC 4.0) license, which permits others to distribute, remix, adapt, build upon this work non-commercially, and license their derivative works on different terms, provided the original work is properly cited, appropriate credit is given, any changes made indicated, and the use is non-commercial. See: http://creativecommons.org/licenses/by-nc/4.0/.

\section{REFERENCES}

1. Varnai P, Rentel M, Dave A, et al. The impact of collaboration: the value of UK medical research to EU science and health. Technopolis Group 2017:1-82.

2. Freshwater D, Sherwood G, Drury V. International research collaboration. Int J Nurs Res 2006;11:295-303.

3. Luukkonen T, Tijssen RJW, Persson O, et al. The measurement of international scientific collaboration. Scientometrics 1993;28:15-36.

4. Witze A. Research gets increasingly international. Nature 2016;785:6-8.

5. Grathwol RP. The world through a different window: an international perspective on research. Physiologist 2005;48:169-71.

6. Dale R, Robertson S. Globalisation and Europeanisation in education. Oxford: Symposium Books Ltd, 2009.

7. Hayati Z, Didegah F. International scientific collaboration among Iranian researchers during 1998-2007. Library Hi Tech 2010;28:433-46.

8. Bettcher D, Lee K. Globalisation and public health. J Epidemiol Community Health 2002;56:8-17.

9. Kim K-W. Measuring international research collaboration of peripheral countries: taking the context into consideration. Scientometrics 2006;66:231-40.

10. McKee M, Gilmore AB, Schwalbe N. International cooperation and health. Part I: Issues and concepts. J Epidemiol Community Health 2005;59:628-31.

11. McKee M, Gilmore AB, Schwalbe N. International cooperation and health. Part 2: Making a difference. J Epidemiol Community Health 2005;59:737-9.

12. United Nations Security Council. UN Security Council resolution 1929, 2010. Available: https://undocs.org/S/RES/1929(2010) [Accessed 27 Dec 2018].

13. US Department of State. Joint Plan of Action (JPOA) archive and Joint Comprehensive Plan of Action (JCPOA) archive, 2018. Available: https://www.treasury.gov/resource-center/sanctions/ Programs/Pages/jpoa_archive.aspx [Accessed 27 Dec 2018].

14. Mulligan SP. Withdrawal from international agreements: legal framework, the Paris agreement, and the Iran nuclear agreement. Congressional Research Service 2018:1-28.

15. World Health Organization. Country cooperation strategy for WHO and the Islamic Republic of Iran 2010-2014. WHO regional office for the Eastern Mediterranean, 2010. Cairo. Available: http://apps. who.int/iris/bitstream/10665/113238/1/CCS_Islamic_Republic_Iran 2010_EN_14482.pdf [Accessed 31 May 2019]. 
16. US Department of the Treasury. Sanctions programs and country information, 2018. Available: https://www.treasury.gov/resourcecenter/sanctions/Programs/Pages/Programs.aspx [Accessed 15 Sep 2018].

17. Kokabisaghi F. Economic sanctions as social determinants of health. Shiraz E-Med J 2017;18(Suppl):e58662.

18. Mousavi S, Jokar F, Mohammadi A. US unilateral sanctions against Iran; contradiction in slogan and conduct, extreme politicization of human rights. Pub Law Res 2015;16:149-73.

19. Mousavi SFJ, Mohammadi O, Roshan NAM, et al. The impacts of economic sanctions on sustainable development: focusing on labor. Cumhuriyet Sci J 2015;36:3458-76.

20. Kokabisaghi F. Assessment of the effects of economic sanctions on Iranians' right to health by using human rights impact assessment tool: a systematic review. Int J Health Policy Manag 2018;7:374-93.

21. Six charts that show how hard US sanctions have hit Iran, 2019. BBC News. Available: https://www.bbc.com/news/world-middleeast-48119109 [Accessed 31 May 2019].

22. Kheirandish M, Varahrami V, Kebriaeezade A, et al. Impact of economic sanctions on access to noncommunicable diseases medicines in the Islamic Republic of Iran. East Mediterr Health J 2018;24:42-51.

23. Namazi S. Sanctions and medical supply shortages in Iran. Viewpoints 2013;20:1-9.

24. Moret ES. Humanitarian impacts of economic sanctions on Iran and Syria. Eur Sec 2015;24:120-40.

25. Massoumi RL, Koduri S. Adverse effects of political sanctions on the health care system in Iran. J Glob Health 2015;5:020302.

26. Aloosh M, Salavati A, Aloosh A. Economic sanctions threaten population health: the case of Iran. Public Health 2019;169:10-13.

27. Asadi-Pooya AA, Azizimalamiri R, Badv RS, et al. Impacts of the International economic sanctions on Iranian patients with epilepsy. Epilepsy Behav 2019;95:166-8.

28. Ghiasi G, Rashidian A, Kebriaeezadeh A, et al. The impact of the sanctions made against Iran on availability to asthma medicines in Tehran. Iran J Pharm Res 2016;15:567-71.

29. Institute for Health Metrics and Evaluation. Global health data exchange. Seattle: University of Washington, 2019.

30. Deilamizade A, Esmizade S. Economic sanctions against Iran, and drug use in Tehran, Iran: a 2013 pilot study. Subst Use Misuse 2015;50:859-68

31. Shariatirad S, Maarefvand M. Sanctions against Iran and the impact on drug use and addiction treatment. Int J Drug Policy 2013;24:636-7.

32. Hosseini Divkolaye NS, Burkle FM, Frederick M. The enduring health challenges of Afghan immigrants and refugees in Iran: a systematic review. PLoS Curr 2017;9. doi:10.1371/currents.dis.449b4c549951 e359363a90a7f4cf8fc4. [Epub ahead of print: $21 \mathrm{Jul} 2017$ ].

33. International Healthcare Association. Health tourism in Iran and the Middle East, 2018. Available: http://internationalhta.com/ [Accessed 27 Dec 2018].

34. Mundi I. Iran demographics profile 2018, 2018. Available: https:// www.indexmundi.com/iran/demographics_profile.html [Accessed 27 Dec 2018]

35. Statistical Center of Iran. Iranian urban and non-urban population trends, 2018. Available: https://www.amar.org.ir/english [Accessed 5 Jan 2019].

36. Growth by $2500 \%$ of students and universities after the revolution, 2018. Tasnim news. Available: https://www.tasnimnews.com/fa/ news/1396/11/18/1649269 [Accessed 27 Dec 2018].

37. United Nations. United Nations common country assessment for the Islamic Republic of Iran, 2003. United nations. Available: http://www. tr.undp.org/content/dam/rbap/docs/programme-documents/cca/IRCCA-2003.pdf [Accessed 27 Dec 2018].
38. Alpay S, Maxton J. The atlas of Islamic world science and innovation. Organization of Islamic Cooperation 2015:1-49.

39. Cornell University, INSEAD, World Intellectual Property Organization. Global innovation INDEX 2018: Energizing the world with innovation. 11th ed. Ithica, Fontainebleau, and Geneva, 2018. Available: https://www.globalinnovationindex.org/Home [Accessed 5 Jan 2019].

40. SCIMAGOJR. Scimago Journal and country RANK. Available: https://www.scimagojr.com/ [Accessed 1 Nov 2018].

41. World Bank Open Data. GDP (current US\$): World Bank national accounts data, and OECD national accounts data files, 2018. Available: https://data.worldbank.org/indicator/NY.GDP.MKTP.CD [Accessed 5 Jan 2019].

42. Mozafari M. Iran and science publishing in the post-sanctions era. The Lancet 2016;387:1721-2.

43. Abramson JH. PEPI-for-Windows: computer programs for epidemiologists. Epidemiol Perspect Innov 2004;1.

44. Scopus. Publishing trends, 2018. Available: https://www.Scopus. com [Accessed Nov 2018].

45. Rezaee-Zavareh MS, Karimi-Sari H, Alavian SM. Iran, sanctions, and research collaborations. The Lancet 2016;387:28-9.

46. Haricombe LJ. Combining qualitative and quantitative methodologies to study the effects of an academic boycott on academics in South Africa. Libr Q 1993;63:508-27.

47. Sansom C. The ghost of Saddam and UN sanctions. Lancet Oncol 2004;5:143-5.

48. Arie S. Unintended consequences of sanctions against Iran. BMJ 2013;347:f4650.

49. Marshall E. Scientific journals adapt to new U.S. trade sanctions on Iran, 2013. Science. Available: http://www.sciencemag.org/news/ 2013/05/scientific-journals-adapt-new-us-trade-sanctions-iran [Accessed 27 Dec 2018]

50. Seeley M. How sanctions laws affect publishing: OFAC provides new guidance: Elsevier has encouraged "freedom of expression" for scientific authors in sanctioned countries such as Iran, Cuba, Sudan, Burma and Syria. Elsevier, 2015. Available: https://www.elsevier. com/connect/how-sanctions-laws-affect-publishing-ofac-providesnew-guidance [Accessed 17 Aug 2018]

51. Lankarani KB, Mahmoodi M, Gholami S, et al. Reducing social disparity in liver transplantation utilization through governmental financial support. Hepat Mon 2012;12:e6463.

52. Seeley M. Trade sanctions against Iran affect publishers: Elsevier explains legal issues to its editors and works with publishers and research community to pursue 'balance in the law'. Elsevier, 2013. Available: https://www.elsevier.com/connect/trade-sanctionsagainst-iran-affect-publishers [Accessed 17 Aug 2018].

53. Zarghami M. Illogical and unethical scientific sanctions against Iranian authors. Iran J Psych Behav Sci 2013;7:1-4.

54. Afshari R, Bhopal RS, Iran BRS. Iran, sanctions, and collaborations. The Lancet 2016;387:1055-6.

55. Rose H, Rose S, Israel RS. Israel, Europe and the academic boycott Race Cl 2008;50:1-20.

56. The Editors of The Lancet. Iran and science publishing: an open letter - editors' reply. Lancet 2013;382:596.

57. Stone $R$. Science in Iran languishes after Trump reimposes sanctions, 2018. Science. Available: http://www.sciencemag.org/ news/2018/08/science-iran-languishes-after-trump-re-imposessanctions [Accessed 27 Dec 2018]

58. Stone R. Renewed sanctions strangle science in Iran. Science 2018;361:961.

59. Miller A, Ziad-Miller A. United States federal government regulation of international research collaborations: what every physicianscientist should know. Int J Crit IIIn Inj Sci 2019;9:5. 